\title{
An Empirical Study on Logistics Performance of Ningxia Region, China
}

\author{
LIANG HUA \\ PhD Scholar Faculty of Business and Law, Taylor's University \\ Selangor Darul Ehsan, Malaysia. \\ Email: stevenliang980622@gmail.com \\ FILZAH MD ISA \\ Associate Professor, Faculty of Business and Law, Taylor's University \\ Selangor Darul Ehsan, Malaysia. \\ Email: filzah.dIsa@taylors.edu.my

\section{SHAISTA NOOR} \\ PhD Scholar Faculty of Business and Law, Taylor's University, \\ Selangor Darul Ehsan, Malaysia. \\ Email: shaistanoor25@gmail.com
}

\begin{abstract}
The primary purpose of this paper is to test a theoretical model based on the resource-based view (RBV) theory and investigate the determinant factors influencing the logistics performance among 412 leading logistic companies in Ningxia region, China. The study addresses the two research questions (1) To what extent intra-firm resources, inter-firm relationships, and the logistics service capability, influence the logistics performance in China? (2) How does logistics service capability mediate the relationships between intra-firm resources, inter-firm relationships, and logistics performance in the Chinese logistics industry? The main theoretical contribution of this research is to better understand the significant roles of determinant factors (intra-firm resources and inter-firm relationships) on logistic performance. From a practical perspective, testing results may help the logistics managers to attain sustainable logistics performance effectively. The present study also focuses on the mediating role of logistics service capability on the relationships between intra-firm resources and inter-firm relationships with logistics performance. The findings revealed that logistics service capability acts as an essential mediator for enhancing the performance of logistics companies in China. Consequently, the result may provide information on the personalized services that can create maximum value for the logistics industry's clients. The implications of the study, limitations, and recommendations for future research are subsequently discussed.
\end{abstract}

Keywords: China, Logistic Performance, Inter-Firm Relationships, Intra-Firm Resources, Service Capability.

\section{Introduction}

The Chinese Government considered the logistics as a strategic industry and massive investments done to strengthen the logistics resources, involving multimodal transportation networks, port upgrades, large-scale warehousing, and logistics equipment along with facilities for distributions (Chen, 2007). The total cost of Chinese logistics as a percentage of gross domestic product (GDP) is double as compared to various developed countries such as Germany and Japan (World Bank, 2018). Besides, the inadequate deployment of resources, fewer competencies in terms of strengthening and establishment of inter-firm relationships 
and lack of logistics service awareness among clients are also influencing logistics performance. Hence, these are categorised as determinants factors that impede further development of Chinese logistics (Chen, Tian, Ellinger, \& Daugherty, 2010). Currently, the Chinese Government initiated a step for the advancement of logistics systems involving domestic and cross-border (Hwang, Hong, \& Lee, 2017; Yang, Yang, Lirn, \& Lirn, 2017). Thus, to survive in a competitive market, firms need to gain sustainable logistics performance to be competitive in the changing market environment (Lai, Wang, \& Fan, 2013). As Hwang et al. (2017) stated, the low performance of Chinese Logistics is directly proportional to high cost, which is becoming the main reason to inhibit the growth and expansion of the logistics industry in China. The present study reviews the strategic and logistics literature to identify the main issues that influence Chinese logistics performance, such as intra-firm resources, inter-firm relationships, and logistics service capability. Subsequently, these factors are examined to ascertain their influence on logistics performance. The findings of the study will fill the potential gaps and help the logistics practitioners in Ningxia, China, to further improve their logistics performance.

\section{Literature Review}

\section{Logistics Performance}

Previous literature highlights that logistics performance measures comprise of "hard" criteria, (costs and accounting-based indicators) and "soft" criteria, namely, logistics service quality and speed, and customer satisfaction and loyalty (Chia, Goh, \& Hum, 2009; Chow, Heaver, \& Henriksson, 1994; Chu \& Wang, 2012; Han, Trienekens, \& Omta, 2009; Lee, Seo, \& Dinwoodie, 2016; Shang \& Marlow, 2005). However, the majority of the researchers systematically and strategically integrate various measures of logistics performance in existing logistics literature (Fugate, Mentzer, \& Stank, 2010; Langley \& Holcomb, 1992; Mentzer \& Konrad, 1991; Yang et al., 2017). As Chow et al. (1994) highlighted in their study, both "hard and soft" measures are related to strengths and weaknesses in the process of judgment of logistics performance as they are integrated as efficiency and effectiveness to measure logistics performance (Bobbitt, 2004; Fugate et al., 2010; Yang et al., 2017). Thus, the differentiation created by either a hard or soft measure is considered as a new indicator of logistics performance since firms used it to differentiate their inimitable logistics activities from competitors to attain a superior logistics performance (Langley \& Holcomb, 1992; Fugate et al., 2010). Therefore, the present study measures logistics performance in terms of efficiency, effectiveness, and differentiation.

\section{RBV Theory}

The resource-based view (RBV) theory is introduced in logistics literature for the development of strategies that are considered as a correlation between resources and performance (Mahoney, 1995; Mentzer, Min, \& Michelle Bobbitt, 2004). This theory stresses that the attainment of better performance as compared to competitors lies in acquiring, accumulating, utilizing, protecting and deploying heterogeneous resources (Barney, 1991). Thus, the RBV is recognized as a leading theory, which is broadly applied in logistics studies (Chen et al., 2010; Richey, Daugherty, \& Roath, 2007). Therefore, the RBV is chosen as the appropriate theory for the present study.

\section{The Link between Intra-firm Resources and Logistics Performance}

The competitive advantage of a firm originates from the strengths of intra-firm resources (Barney, 1991; Leuschner, Carter, Goldsby, \& Rogers, 2014; Morash, Droge, \& Vickery, 1996). Therefore, firms can develop, acquire and deploy intra-firm resources to achieve a remarkable logistics performance (Yang, Marlow, \& Lu, 2009). In this regard, the resource heterogeneity is the most essential traits of intra-firm resources, whereby, the management of the intra-firm resources is to determine how the heterogeneous resources are utilised in the best manner (Grant, 1991; Newbert, 2008; Olavarrieta \& Ellinger, 1997). In the context of the Chinese logistics industry, the heterogeneous intra-firm resources are used to assist the firms 
to attain superior performance in the integrative strategic process since the resource heterogeneity usually strengthens the intra-firm resources and helps the firms to implement strategies (Zhao, Dröge, \& Stank, 2001). As Grant (1991) suggested, many researchers attempt to assess the intra-firm resources as inconsistency lies with a set of measures to conduct it (Mwangangi, 2016; Newbert, 2007). Hence, the classification of the intra-firm resources into tangible and intangible assets are the simplest and most effective way (Greco, Cricelli, \& Grimaldi, 2013; Shang, 2009). Yang et al. (2017) also suggested that intra-firm resources act as main drivers of Chinese logistics performance and successful implementation of strategies. From the above discussion, the following hypothesis is developed.

Hypothesis 1: Intra-firm resources have a positive link with logistics performance

\section{The Link between Logistics Service Capability and Logistics Performance}

Logistics service capability is considered as the main element for the improvement of Chinese logistics performance (Yang et al., 2009). In many instances, the RBV theory demonstrates that the logistics service capability is also treated as a strategic asset for a firm to achieve its logistics performance (Lai, 2004; Lu \& Yang, 2010). To enhance logistics performance, the Chinese logistics service providers (LSPs) stress on strengthening and extension of customer-based service capabilities to fulfil the customers' requirements (Lai, 2004). In this regard, the firms focus on their logistics service capabilities for excellent service quality and quick response to customers for the attainment of higher logistics performance in a competitive market (Shang, 2009; Shang \& Marlow, 2005; Yang et al., 2017). The logistics industry players too must take strategic steps for the improvement of logistics service capabilities for a strong position in the market. Based on the above discussion, the following hypothesis is postulated.

Hypothesis 2: Logistics service capability has a positive relationship with logistics performance

\section{The Link between Inter-firm Relationships and Logistics Performance}

Prior literature highlights that inter-firm relationships play a remarkable role in the reduction of overall costs in terms of equipment and operational facilities (Barringer \& Harrison, 2000; Bobbitt, 2004; Rai, Pavlou, Im, \& Du, 2012). Therefore, inter-firm relationships are considered as one of the vibrant strategic tools for the accomplishment of overall cost management for enhancing organizational logistics performance (Caglio \& Ditillo, 2008). Thus, the establishment of inter-firm relationships may help Chinese logistics firms to attain heterogeneous resources for high logistics performance (Yang et al., 2017). Simultaneously, inter-firm relationships result in the sharing of each other's strengths and trust-building at all levels of organisation (Doney \& Cannon, 1997; Harbison \& Pekar, 1997). In other words, the establishment of inter-firm relationships among Chinese logistics players can push marketers to perform better logistics functions by building customer trust and the implementation of a strong marketing strategy. Pertaining to this, Yang et al. (2017) highlighted that inter-firm relationships can be considered as a strategic tool to assist firms in the enhancement of logistics performance and competitive advantage.

The following hypothesis is drawn based on the above discussion.

Hypothesis 3: Logistics performance is positively influenced by inter-firm relationships

\section{Hypotheses Regarding the Mediations}

The service capability of the Chinese logistics requires further development and improvement for effective facilitation and deployment of intra-firm resources, overall cost reduction, optimization of logistics process for long-term profitability for the shareholders (Yang et al., 2009, 2017). Hence, the increasing growth of logistics service capabilities has substantially facilitated the intra-firm resources for the implementation of service strategies successfully (Kandampully, 2002). More importantly, managers must integrate the 
available logistics service capabilities with heterogeneous resources to improve customer satisfaction, such as increased service flexibility in terms of distribution and management (Chapman, Soosay, \& Kandampully, 2003; Zhang, Vonderembse, \& Lim, 2005). Lai (2004) and Lin (2007) suggested the differentiation of service capability, which carries competition among various marketing groups where intra-firm resources are sufficiently utilised for a high logistics performance.

Based on the above discussion below mentioned hypothesis is postulated.

Hypothesis 4: Logistics service capability plays the mediation role between intra-firm resources and logistics performance

Subsequently, the service capability in the logistics process may help logistics practitioners to improve customer loyalty, decrease logistics cost, and make market activities more efficient (Daugherty, Chen, \& Ferrin, 2011). Successful strategies can significantly influence the logistics service capability, which increasingly plays an essential role in the establishment and facilitation of inter-firm relationships to create a high logistics performance (Bobbitt, 2004). In the context of Chinese marketing, logistics managers must be aware of the strategic function of logistics service capability in terms of customer loyalty and effective marketing since services are the essence of fundamental skill and capability in creating customer satisfaction. However, in various situations, the firm only relies on internal collaboration, which makes it quite difficult to improve service capability as per the requirements of the market (Yang et al., 2017). This condition requires the firms to seek external strategic partners for attaining the logistics competency. Therefore, logistics service capability is considered as a driving force to establish mutual trust among partners for the attainment of high logistics performance (Politis, Giovanis, \& Binioris, 2014). At the same time, firms should be aware of the strategic role of logistics service capability in terms of creating customer values (Yang et al., 2017). Thus, the enhancement of logistics service capability can drive logistics owners to establish their inter-term relationships for improved logistics performance.

Hypothesis 5: Logistics service capability plays the mediation role between inter-firm relationships and logistics performance

\section{Theoretical Model}

The main theoretical anchor of the present study is about inter-firm resources and inter-firm relationships as they create a bond between logistics service capability and logistics performance. The present study conceptualized the logistics service capability as a mediator, which mediates the relationship of inter-firm resources and inter-firm relationships with the logistics performance (Chapman, Soosay, \& Kandampully, 2003; Zhang et al., 2005).

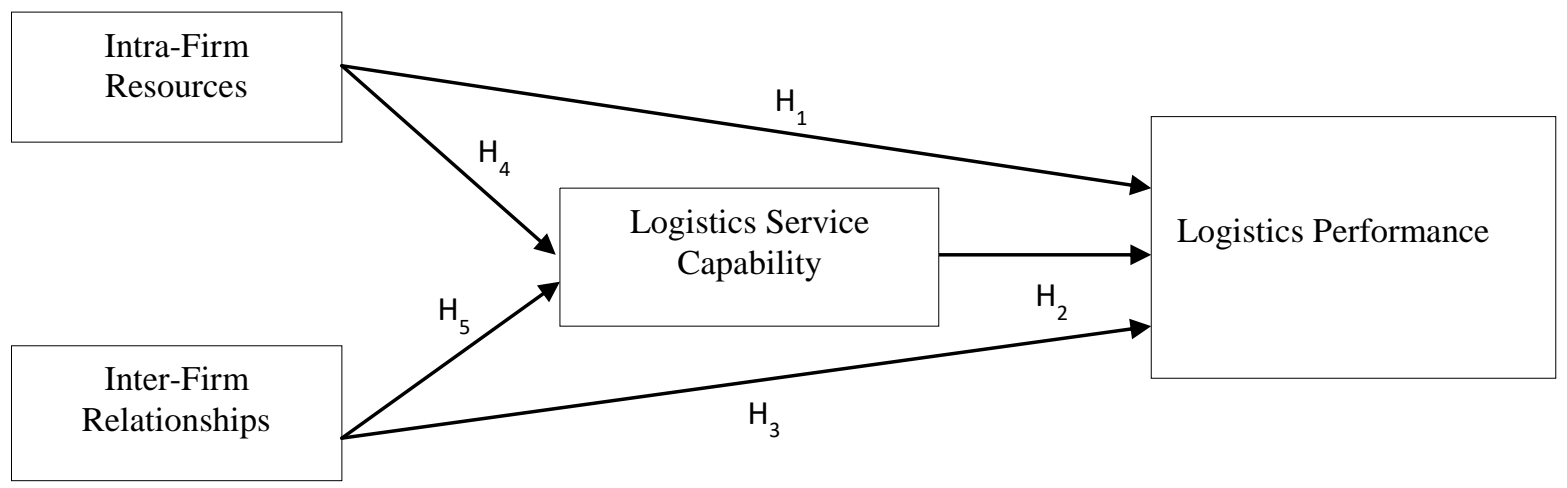

Figure 1: Research Framework 
Hence, conceptualization confirms the validation of the research framework. The theoretical framework consists of two independent variables (inter-firm resources, inter-firm relationships) with logistics service capability the mediator and logistics performance as the main dependent variable. The effect and influence of independent variables on the dependent variable, namely logistics performance, are governed by the underpinning theory of RBV (Barney, 1991). Figure 1 depicts the theoretical framework of the study.

\section{Methodology}

\section{Sampling and Respondent Profile}

A total of 412 surveys questionnaire using the 6-point Likert scale was sent to the management staff such as top managers, logistics managers, supervisor and logistics industry experts in Ningxia region. A total of 251 usable questionnaires was returned which highlighted a valid response rate of $60.9 \%$ approximately. The response rate of $60.9 \%$ is considered relatively high as compared to previous studies on Chinese logistics which using the self-administered questionnaire survey (CFLP, 2018; Hwang et al., 2017). The usable 251 questionnaires were subsequently used for the data analysis.

The questionnaire survey included four variables, namely intra-firm resources which was measured by the scales developed by (Yang et al., 2017). Secondly, inter-firm relationships was measured using scales developed by (Lyles \& Salk, 1996; Panayides \& So, 2005a; Panayides \& So, 2005b; Whipple \& Frankel, 2000; Yang et al., 2017), whereas, logistics service capability was measured using the scales introduced by (Daugherty et al., 2011; Yang et al., 2017; Zhao et al., 2001). Finally, logistics performance was measured by the scales derived from the previous studies done by (Bobbitt, 2004; Fugate et al., 2010; Yang et al., 2017).

The sample of the present study comprised of top managers (9.2\%), logistics managers (26.3\%), supervisors $(51.4 \%)$ and logistics industry experts $(13.1 \%)$ that represented the management staff. These target participants were chosen from the leading logistics companies of Ningxia China and have professional knowledge and work experiences in the field of logistics. Regarding the respondents' educational background, $53 \%$ of participants having a degree while $31.8 \%$ with a diploma certificate in logistics, whereas, $7.2 \%$ of respondents having a Master's degree and above.

The remaining $6 \%$ have a high school certificate, and only $1.6 \%$ or 4 participants have middle school certificates. The results highlight that the majority of the respondents have an education qualification. Regarding years of service, $37 \%$ of respondents are working with their company for more than five years whereas, $23.9 \%$ of respondents are working more than three years but less than five years and $28.3 \%$ are working between 1 and 3 years. However, the remaining (10.8\%) have less than one year of the service period.

\section{Data Analysis}

SPSS software and PLS-SEM technique were used to test the reflective measurement model. SPSS was used to examine the data for descriptive analysis. As noted by Thatcher and Perrewe (2002), the measurement and structural models should be examined by using the PLS. The researchers have extensively applied the PLS-SEM approach to assess the measurement model and provided robust results (Choi, Sung, Lee, \& Cho, 2011; Ringle, Sarstedt, \& Straub, 2012).

To assess the measurement model (outer model), the testing results regarding composite reliability, convergent validity, and discriminant validity (cross-loadings, Fornell-Larcker criterion, and HeterotraitMonotrait (HTMT)) are reported. For evaluating the structural model the significance of path coefficients and mediating effects of logistics service capability were tested via PLS-SEM bootstrapping. 


\section{Findings}

\section{Descriptive analysis}

The statistical results demonstrate that variables rated by respondents according to the scales such as $1=$ strongly disagree to $6=$ strongly agree. The respondents stated the importance of the determinant factors for the improvement of logistics performance as; intra-firm resources (mean $=5.371$, standard deviation $=0.703$ ), and inter-firm relationships (mean $=5.433$, standard deviation=0.617). Refer to Table 1 . Logistics performance shows a mean value of 5.331 and a standard deviation of 0.660 , which implicates that the participants agreed that it is an essential outcome of the study. Logistics service capability (mean $=5.402$, standard deviation $=0.623$ ) acts as an important mediator to the relationships under study. Hence, the descriptive analysis of the present study shows satisfactory results.

\section{Measurement Model}

For the evaluation of the internal consistency reliability and convergent validity, the composite reliability (CR) and average variance extracted (AVE) are computed by using PLS algorithm in the measurement model (Chin, 1998; Fornell \& Larcker, 1981; Hair, Hult, Ringle, \& Sarstedt, 2017). The CR of 0.70 or greater is treated as an acceptable level for a study, as well as the AVE of all measures exceeds the cut-off value of 0.50 (Fornell \& Larcker, 1981). Hair, Hult et al. (2017) highlighted outer loadings of indicators between 0.40 and 0.70 must be considered for removal from the scale only when the deleted indicators increase the CR or the AVE, instead of automatically eliminating indicators when their outer loadings are less than 0.70 . Refer to Table 1.

Traditionally, two types of criteria that comprise the cross-loading criterion and Fornell and Larcker criterion are available to evaluate the discriminant validity of the constructs (Hair, Sarstedt, Hopkins, \& Kuppelwieser, 2014). Cross loading criterion refers to the indicators' loadings on the designated latent variable that must be higher than the loadings on all other latent variables. Otherwise, the indicators of different constructs are not available to be inter-changeable (Ramayah, Cheah, Chuah, Ting, \& Memon, 2018). Also, Chin (1998) suggested that the difference between loadings across latent variables should not be less than 0.1 . Refer to Table 2 .

Subsequently, the Fornell-Larcker criterion is used to assess appropriate discriminant validity. Fornell and Larcker criterion suggested that the items should load stronger in their constructs than with any other constructs in this model, and which has been generally applied to examine the extent to the degree of shared variance between the latent variables (Fornell \& Larcker, 1981). Previous studies also proved that the levels of the square root of the AVE for each construct should be greater than the highest correlation with any other constructs (Fornell \& Larcker, 1981; Hair, Hult et al., 2017; Ramayah et al., 2018). Table 1 indicates that all the values of the square roots of AVE for the constructs presented in the correlation matrix along diagonal are more significant than the off-diagonal correlations in the corresponding rows or columns.

Finally, Henseler, Ringle, and Sarstedt (2015) suggested that Heterotrait-Monotrait (HTMT) technique is the third method that is used to assess discriminant validity. The HTMT ratio that is greater than the HTMT.85 value of 0.85 (Kline, 2015) or HTMT.90 value of 0.90 (Gold et al., 2001) indicates a problem of discriminant validity. Table 3 demonstrates that discriminant validity has been detected, however not all the values meet the criterion of HTMT.85 and HTMT.90. It indicates that there exists an issue of discriminant validity between all constructs in the measurement model. However, Hair, Hult et al. (2017) also highlighted that if a confidence interval of HTMT values for the path coefficients of the structural model includes the value of 1 , in this case, which demonstrates that there is lack of discriminant validity between all constructs in the measurement model. Table 3 also shows the result of HTMT inference that the 95\% bootstrapped confidence interval $(95 \%$ Boot $\mathrm{CI})$ does not have a value of 1 on any of the constructs. 
Simultaneously, this result also provides a shred of evidence that constructs in this study have acceptable discriminant validity.

Table 1: Means, standard deviations, CR, AVE, and correlation of constructs

\begin{tabular}{|l|c|c|c|c|c|c|c|c|}
\hline \multicolumn{1}{|c|}{ Construct } & Mean & $\begin{array}{c}\text { Std. } \\
\text { Dev. }\end{array}$ & CR & AVE & \multicolumn{5}{c|}{ Correlation of constructs } \\
\hline & & & & & 1 & 2 & 3 & 4 \\
\hline (1) Inter-firm Relationships & 5.433 & 0.617 & 0.961 & 0.861 & $\mathbf{0 . 9 2 8}$ & & & \\
\hline (2) Inter-Firm Resources & 5.371 & 0.703 & 0.951 & 0.906 & 0.819 & $\mathbf{0 . 9 5 2}$ & & \\
\hline (3) Logistics Service Capability & 5.402 & 0.623 & 0.968 & 0.857 & 0.892 & 0.834 & $\mathbf{0 . 9 2 6}$ & \\
\hline (4) Logistics Performance & 5.331 & 0.660 & 0.947 & 0.856 & 0.807 & 0.752 & N/A & $\mathbf{0 . 9 2 5}$ \\
\hline
\end{tabular}

Table 2: Factor loadings and cross-loadings

\begin{tabular}{|l|c|c|c|c|}
\hline & IFREL & IFRES & LOGSCAP & LOGPER \\
\hline IFC & $\mathbf{0 . 9 2 1}$ & 0.862 & 0.820 & 0.766 \\
\hline LTR & $\mathbf{0 . 9 3 1}$ & 0.766 & 0.797 & 0.723 \\
\hline SA & $\mathbf{0 . 9 3 9}$ & 0.801 & 0.840 & 0.757 \\
\hline JV & $\mathbf{0 . 9 2 1}$ & 0.823 & 0.851 & 0.747 \\
\hline TA & 0.802 & $\mathbf{0 . 9 4 7}$ & 0.760 & 0.666 \\
\hline IA & 0.863 & $\mathbf{0 . 9 5 7}$ & 0.824 & 0.761 \\
\hline LSE & 0.831 & 0.774 & $\mathbf{0 . 9 3 4}$ & 0.785 \\
\hline LSF & 0.827 & 0.811 & $\mathbf{0 . 9 3 4}$ & 0.802 \\
\hline LSI & 0.801 & 0.734 & $\mathbf{0 . 9 2 7}$ & 0.836 \\
\hline LSREL & 0.850 & 0.780 & $\mathbf{0 . 9 0 9}$ & 0.776 \\
\hline LSRES & 0.818 & 0.759 & $\mathbf{0 . 9 2 5}$ & 0.892 \\
\hline LOGEFFI & 0.780 & 0.712 & 0.869 & $\mathbf{0 . 9 4 7}$ \\
\hline LOGEFFE & 0.704 & 0.657 & 0.759 & $\mathbf{0 . 9 1 1}$ \\
\hline LOGDIFF & 0.752 & 0.716 & 0.823 & $\mathbf{0 . 9 1 8}$ \\
\hline
\end{tabular}

Notes: (a) Bold values are loadings for items which are above the recommended value of 0.70 . (b) interfirm relationships (IFREL): inter-firm communication (IFC), long-term relationships (LTR), strategic alliance (SA), and joint venture (JV); intra-firm resources (IFRES): tangible assets (TA), intangible assets (IA); logistics service capability (LOGSCAP): logistics service reliability (LSREL), logistics service efficiency (LSE), logistics service flexibility (LSF), logistics service innovation (LSI), and logistics service responsiveness (LSRES); logistics performance (LOGPER): logistics efficiency (LOGEFFI), logistics effectiveness (LOGEFFE), and logistics differentiation (LOGDIFF).

Table 3: HTMT Criterion

\begin{tabular}{|c|c|c|c|c|}
\hline \multirow{2}{*}{\multicolumn{5}{|c|}{ IFREL }} \\
\hline & & & & \\
\hline IFRES & $\begin{array}{c}0.949 \\
\text { CI.95 }(0.533,0.744) \\
\end{array}$ & & & \\
\hline LOGSCAP & $\begin{array}{c}0.936 \\
\text { CI.95 }(0.471,0.782) \\
\end{array}$ & $\begin{array}{c}0.898 \\
\text { CI.95 }(0.068,0.343)\end{array}$ & & \\
\hline LOGPER & $\begin{array}{c}0.865 \\
\text { CI.95 }(-0.124,0.290)\end{array}$ & $\begin{array}{c}0.826 \\
\text { CI.95 }(0.381,0.710)\end{array}$ & $\begin{array}{c}0.941 \\
\text { CI.95 }(0.085,9.380)\end{array}$ & \\
\hline
\end{tabular}




\section{Structural Model}

The structure model tests the hypothesized relationships of the structural model. The structural model is assessed by running the PLS algorithm and bootstrapping procedures (Chin, 2010; Gefen, Straub, \& Boudreau, 2000). To assess this model, the significance of path coefficients and t-values was calculated and presented. Furthermore, the mediating effects of logistics service capability also calculated and analyzed.

\section{Assessing Direct Relationships}

This section presented the results of the direct effects among the constructs comprising of intra-firm resources (IFRES), inter-firm relationships (IFREL), logistics service capability (LOGSCAP), and logistics performance (LOGPER). The hypotheses testing in the model was conducted by using bootstrapping routine 1,000 iterations. The bootstrapping sample size was correlated with the significances of $\mathrm{p}<0.05$ for $\mathrm{t}>1.645$, and $\mathrm{p}<0.01$ for $\mathrm{t}>2.33$ (Hair, Anderson, Babin, \& Black, 2010).

Path coefficients were generated for hypotheses testing and the corresponding t-values of hypotheses were greater than the critical value $(\mathrm{p}<0.01$ for $\mathrm{t}>2.33$ ). Figures $2 \& 3$ show a two-procedure approach that is by using the PLS algorithm and bootstrapping to assess the significance of the direct path coefficient of the structural model. Table 4 demonstrates the testing results that direct relationships among the constructs were positive and significant, except the relationship between inter-firm resources (IFREL) and logistics performance (LOGPER) failed to receive empirical support.

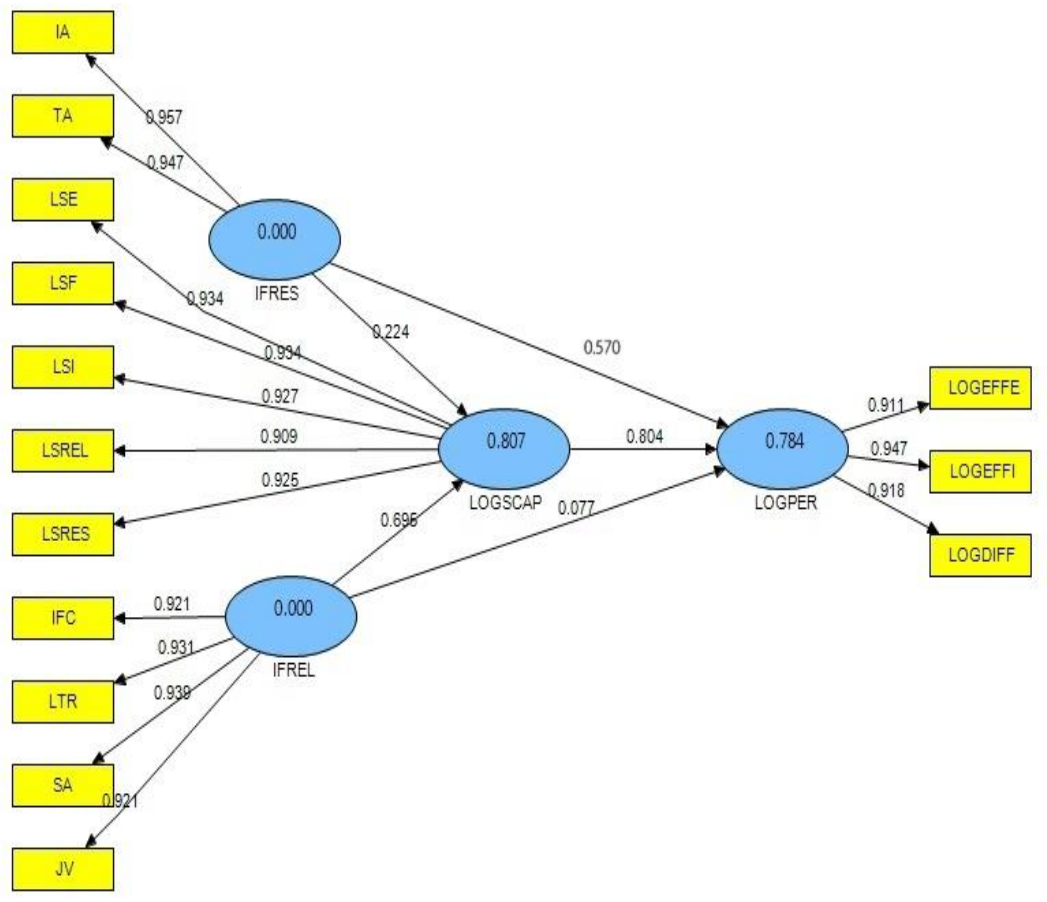

Figure 2: Direct path coefficient of the structural model (PLS algorithm) 


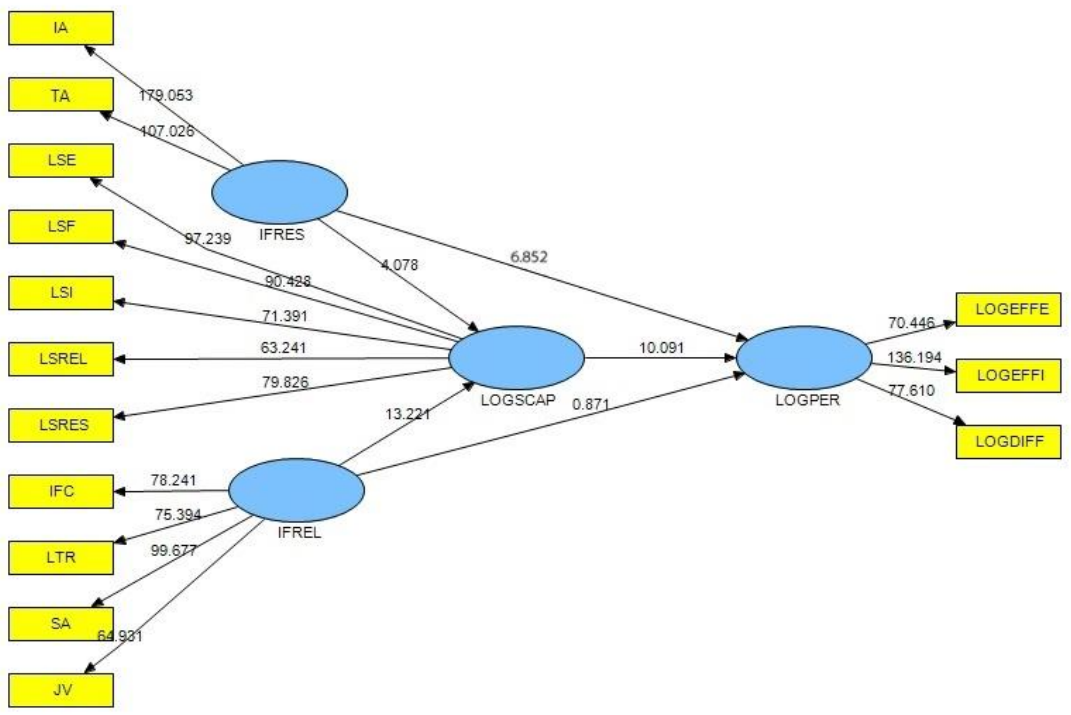

Figure 3: Direct path coefficient of the structural model (PLS bootstrapping)

Table 4: Hypotheses testing results

\begin{tabular}{|l|c|c|c|c|c|}
\hline \multicolumn{1}{|c|}{ Direct path } & Beta $(\beta)$ & SE & T-value & P-value & Decision \\
\hline IFRES $\rightarrow$ LOGPER & 0.566 & 0.074 & 6.852 & 0.000 & supported \\
\hline LOGSCAP $\rightarrow$ LOGPER & 0.804 & 0.080 & 10.091 & 0.000 & supported \\
\hline IFREL $\rightarrow$ LOGPER & 0.077 & 0.089 & 0.871 & 0.385 & Not supported \\
\hline IFRES $\rightarrow$ LOGSCAP & 0.224 & 0.055 & 4.078 & 0.000 & supported \\
\hline IFREL $\rightarrow$ LOGSCAP & 0.695 & 0.053 & 13.221 & 0.000 & supported \\
\hline
\end{tabular}

Note: $(\mathrm{a}) * \mathrm{P}<0.05(\mathrm{t}>1.645) ; * * \mathrm{P}<0.01(\mathrm{t}>2.33)$

\section{Assessing the Mediating Role of Logistics Service Capability}

The PLS bootstrapping procedure was applied to generate the bootstrap results for the direct effects, such as (path a) and (path b). Refer to Figure 4. In a different view, Nitzl, Roldan, and Cepeda (2016) suggested that it is important for a more detailed mediating analysis to calculate the bootstrapped results for the combination of $\mathrm{a} \times \mathrm{b}$ of a specific indirect effect (IE) in a new column. Thus, several steps are followed to assess the mediating effects of the constructs. Firstly, Hair, Hult et al. (2017) suggested that the new column of the indirect effect (IE) point estimate computed to identify the standard error (SE) of its distribution. Regarding the data standardized, the function "STDEV" in an excel spreadsheet was implemented to calculate SE for all IE. Subsequently, t-values for all indirect effects were computed based on the formula of $\mathrm{t}$-value calculation $(\mathrm{t}=\mathrm{IE}$ point estimate / $\mathrm{SE}=(\mathrm{a} * \mathrm{~b}) / \mathrm{SE})$. Finally, Hayes (2009) suggested that the subsamples (1000) for the values of $\mathrm{a} \times \mathrm{b}$ should be sorted from smallest to largest to determine the $95 \%$ bootstrapped confidence interval (95\% Boot CI). The IE point estimate, $t$-values of all indirect effects, and LB/UB are presented in Table 5. The calculating results of $(\beta=0.180, t=3.750, p<0.01$; $\beta=0.559, t=7.658, \quad p<0.01)$ demonstrates that the mediating effects of logistics service capability (LOGSCAP) on the relationships between intra-firm resources (IFRES), inter-firm relationships (IFREL), and logistics performance (LOGPER) show positive and significant. Also, percentile 95\% did not straddle a 0 in between. 


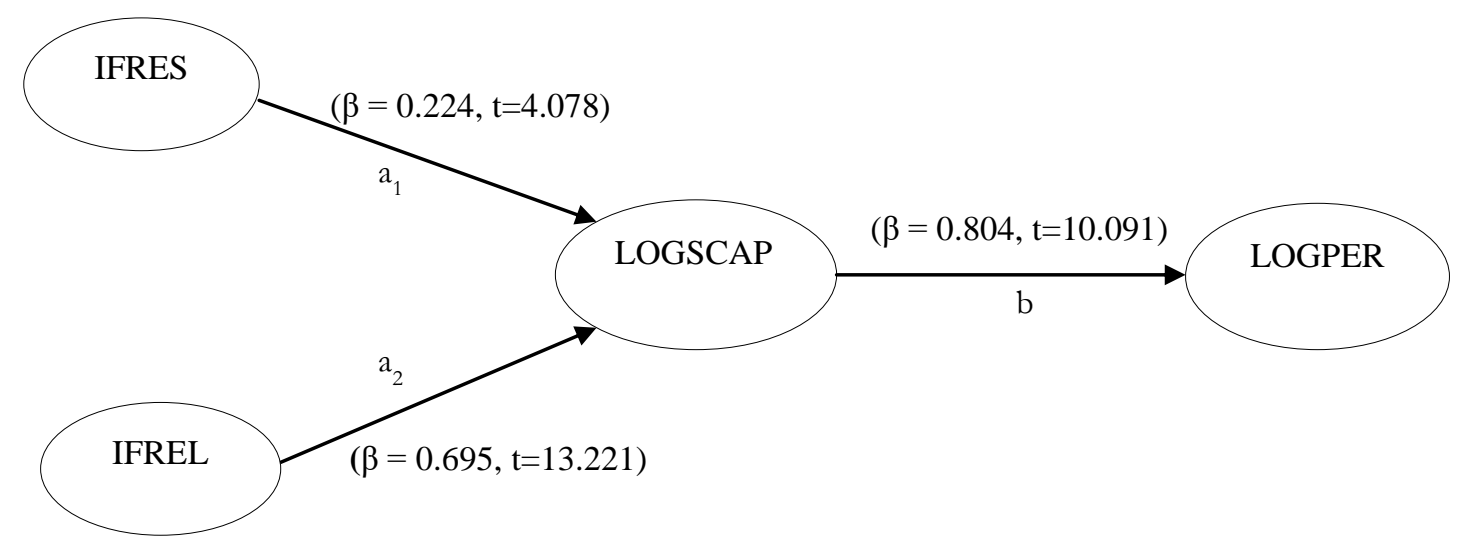

Figure 4: Direct path coefficients of the structural model for mediation effect assessment

Table 5: Calculating IE point estimate, SE, t-value and LB/UB

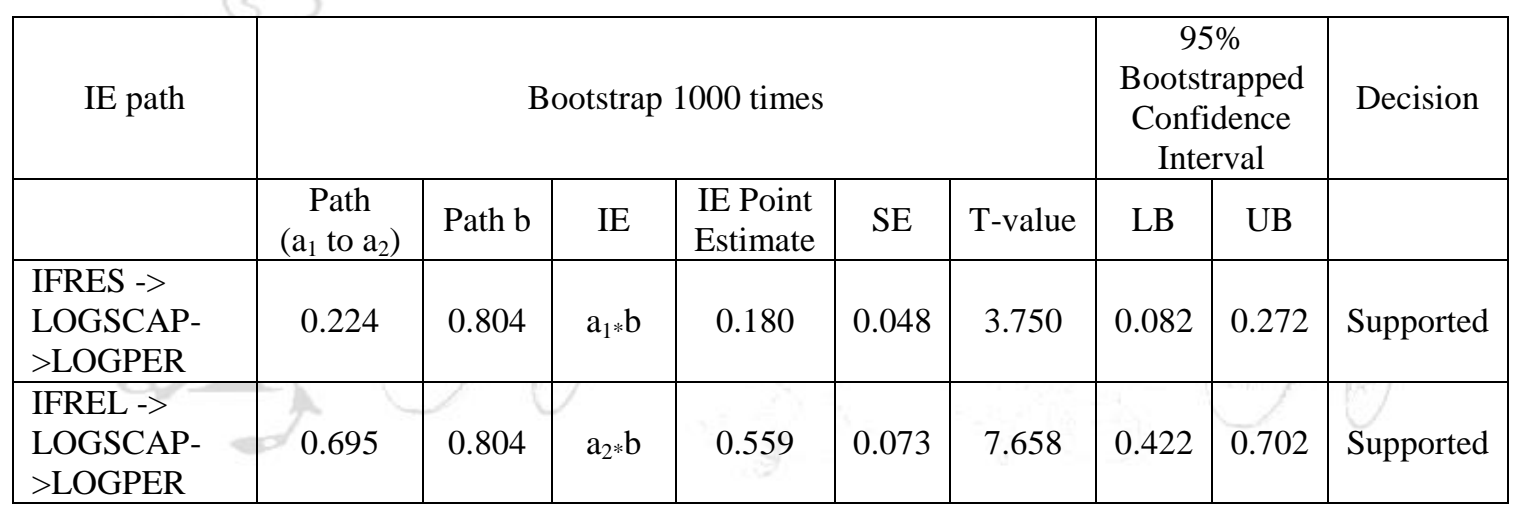

Note: (a) $* \mathrm{P}<0.05(\mathrm{t}>1.96) ; * * \mathrm{P}<0.01(\mathrm{t}>2.58)$; (b) Lower Bound (LB); Upper Bound (UB)

\section{Discussion}

The findings demonstrate that both intra-firm resources and logistics service capability positively and significantly influence on improved logistics performance in the context of the Chinese logistics industry. However, the finding of this study does not empirically support the proposition that the establishment of inter-firm relationships results in gaining sustained logistics performance (Yang et al., 2017). This finding contradicts the previous studies results, which requires to be involved in current studies as it is the central part of a higher logistics performance work system (Caglio \& Ditillo, 2008). Subsequently, the finding is also consistent with the study of Bobbitt (2004). The reason may be that many Chinese logistics enterprises are focusing more on the reduction of logistics costs by the establishment of inter-firm relationships instead of considering how these relationships that have already been built can enhance logistics performance. Besides, the service capability in the logistics process serves as a mediator that drives the efficient deployment of a firm's internal resources and facilitates the development and establishment of relationships between the firm and its partners for an excellent logistics performance. The testing results have provided for real-world practices that firms should effectively deploy their resources, whatever formed inside or attained from a market to achieve the interactive functions throughout logistics activities for the enhancement of logistics performance. The findings further reveal that logistics service providers usually 
prefer to share resources with their partners and establish cooperative relationships to avoid reduplicative investments to improve service capability in the logistics process. In general, this paper sheds light on how the determinant factors influence logistics performance in the Chinese logistics context.

\section{Theoretical Implication}

The theoretical value of this study is to establish the relevance of the RBV theory and explain the relationships among the constructs in the measurement model. This research provides much empirical evidence to narrow the gap in the literature regarding the hypothesized links between the variables and an outcome. The results of this study are consistent with the RBV theory's expectation except for the proposition between inter-firm relationships and logistics performance, which is rejected. The study provides shared ideas for scholars who carry on cross-study. Meanwhile, this research provides a new research direction on the predictors of logistics performance in the Chinese logistics.

\section{Managerial Implication}

This study provides managerial contributions. Firstly, the resource-based approach offers to guide the managers who are involved with logistics to rethink the ways for effective logistics performance. Secondly, this study provides practical ways to help managers in the identification of strategic resources for higher logistics performance. Thirdly, this research may help clients to be fully aware of what they expect to get from firms. Fourthly, this study suggests that firms should be proactive in seizing opportunities when they can seek new ways to compete in the existing markets. Whereas owners or managers also need to optimize their strategies in product development, services, and new processes when they prepare to build a new business or enter a new market/industry. Finally, this study provides the suggestions for policymakers to formulate the policies to benefit firms for improved logistics performance.

\section{Conclusion}

The present study used the RBV theory to establish the theoretical model and investigation of the determinant factors that influence logistics performance and examination of the hypothesized relationships among the constructs in the context of Chinese logistics. This study shows the empirical support of the majority of the hypotheses such as direct relationships between intra-firm resources, logistics service capability, and logistics performance. Nevertheless, the direct link between inter-firm relationships and logistics performance failed for the empirical support. Besides, the mediating effects of logistics service capability on the relationships between intra-firm resources, inter-firm relationships, and logistics performance depict the positive and significant. The findings contribute to the existing literature of logistics industry as well as practitioners for optimizing and deploying their resources for better logistics performance. The present study suggested that the purpose of the establishment of inter-firm relationships is to improve logistics performance rather than merely to reduce costs. More importantly, the findings also demonstrate that logistics service capability acts as a central mediator in enhancing logistics performance.

\section{Limitations of this Study}

The first limitation is not generalizable to other countries since some potential differences in the traits of Chinese logistics and those in other countries. Secondly, this study applies a quantitative method and, different statements provided by the professional respondents could be biased. The target samples of this study are considered acceptable. The subjective measures have been widely adopted in organizational studies as suggested by Tracey (1998). Thus, the validity and reliability of the subjective instruments are established. However, if researchers expect to get an in-depth understanding of the processes and mechanisms by an interview survey, in this case, only the questionnaire survey cannot meet the research objectives. 


\section{Recommendations for Future Research}

The first recommendation for future research is to expand the scope of the study. Thus, future researchers may consider increasing the target population overseas for comparisons of logistics performance across countries. Secondly, the mixed research design, including quantitative and qualitative methods, should be used in future studies for a deeper understanding of the logistics industry. Finally, the longitudinal research design may seize the dynamic attributes of relevant constructs and empirically evaluate their effects on logistics performance. Therefore, a focus on longitudinal research design for future research is recommended.

\section{References}

Barney, J. (1991). Firm resources and sustained competitive advantage. Journal of management, 17(1), 99120.

Barringer, B. R., \& Harrison, J. S. (2000). Walking a tightrope: Creating value through interorganizational relationships. Journal of management, 26(3), 367-403.

Bobbitt, L. M. (2004). An examination of the logistics leverage process: implications for marketing strategy and competitive advantage.

Caglio, A., \& Ditillo, A. (2008). A review and discussion of management control in inter-firm relationships: Achievements and future directions. Accounting, organizations and society, 33(7- 8), 865-898.

CFLP. (2018). “2017nian Zhongguo wuliu yunying zhuangkuang jianbao”(Briefing on China's logistics operation in 2017). [online]http://www.chinawuliu.com.cn (accessed 27 December 2019).

Chapman, R. L., Soosay, C., \& Kandampully, J. (2003). Innovation in logistics services and the new business model: a conceptual framework. International journal of physical distribution \& logistics management, 33(7), 630-650.

Chen, H., Tian, Y., Ellinger, A. E., \& Daugherty, P. J. (2010). Managing logistics outsourcing relationships: An empirical investigation in China. Journal of business Logistics, 31(2), 279-299.

Chen, X. (2007). A tale of two regions in China: Rapid economic development and slow industrial upgrading in the Pearl River and the Yangtze River Deltas. International Journal of Comparative Sociology, 48(2-3), 167-201.

Chia, A., Goh, M., \& Hum, S.-H. (2009). Performance measurement in supply chain entities: balanced scorecard perspective. Benchmarking: An International Journal, 16(5), 605-620.

Chin, W. W. (1998). The partial least squares approach to structural equation modeling. Modern methods for business research, 295(2), 295-336.

Chin, W. W. (2010). How to write up and report PLS analyses Handbook of partial least squares (pp. 655690): Springer.

Choi, J. N., Sung, S. Y., Lee, K., \& Cho, D. S. (2011). Balancing cognition and emotion: Innovation implementation as a function of cognitive appraisal and emotional reactions toward innovation. Journal of Organizational Behavior, 32(1), 107-124.

Chow, G., Heaver, T. D., \& Henriksson, L. E. (1994). Logistics performance: definition and measurement. International journal of physical distribution \& logistics management, 24(1), 17-28.

Chu, Z., \& Wang, Q. (2012). Drivers of relationship quality in logistics outsourcing in China. Journal of Supply Chain Management, 48(3), 78-96.

Daugherty, P. J., Chen, H., \& Ferrin, B. G. (2011). Organizational structure and logistics service innovation. The International Journal of Logistics Management, 22(1), 26-51.

Doney, P. M., \& Cannon, J. P. (1997). An examination of the nature of trust in buyer-seller relationships. The Journal of marketing, 35-51.

Fornell, C., \& Larcker, D. F. (1981). Evaluating structural equation models with unobservable variables and measurement error. Journal of marketing research, 18(1), 39-50.

Fugate, B. S., Mentzer, J. T., \& Stank, T. P. (2010). Logistics performance: efficiency, effectiveness, and differentiation. Journal of business Logistics, 31(1), 43-62. 
Gefen, D., Straub, D., \& Boudreau, M.-C. (2000). Structural equation modeling and regression: Guidelines for research practice. Communications of the association for information systems, 4(1), 7.

Gold, A. H., Malhotra, A., \& Segars, A. H. (2001). Knowledge management: An organizational capabilities perspective. Journal of management information systems, 18(1), 185-214.

Grant, R. M. (1991). The resource-based theory of competitive advantage: implications for strategy formulation Knowledge and strategy (pp. 3-23): Elsevier.

Greco, M., Cricelli, L., \& Grimaldi, M. (2013). A strategic management framework of tangible and intangible assets. European Management Journal, 31(1), 55-66.

Hair Jr, J. F., Hult, G. T. M., Ringle, C., \& Sarstedt, M. (2017). A primer on partial least squares structural equation modeling (PLS-SEM) (second ed.): Sage publications.

Hair Jr, J., Sarstedt, M., Hopkins, L., \& G. Kuppelwieser, V. (2014). Partial least squares structural equation modeling (PLS-SEM) An emerging tool in business research. European Business Review, 26(2), 106-121.

Hair, J. F., Anderson, R. E., Babin, B. J., \& Black, W. C. (2010). Multivariate data analysis: A global perspective (Vol.7): Upper Saddle River, NJ: Pearson.

Han, J., Trienekens, J. H., \& Omta, S. (2009). Integrated information and logistics management, quality management and firm performance of pork processing industry in China. British Food Journal, 111(1), 9-25.

Harbison, J. R., \& Pekar, P. (1997). Cross-border alliances in the age of collaboration. Booz Allen \& Hamilton, 39-51.

Hayes, A. F. (2009). Beyond Baron and Kenny: Statistical mediation analysis in the new millennium. Communication monographs, 76(4), 408-420.

Henseler, J., Ringle, C. M., \& Sarstedt, M. (2015). A new criterion for assessing discriminant validity in variance-based structural equation modeling. Journal of the Academy of Marketing Science, 43(1), 115-135.

Hwang, D. W., Hong, P. C., \& Lee, D. Y. (2017). Critical factors that affect logistics performance: a comparison of China, Japan and Korea. International Journal of Shipping and Transport Logistics, 9(1), 107-129.

Kandampully, J. (2002). Innovation as the core competency of a service organisation: the role of technology, knowledge and networks. European journal of innovation management, 5(1), 18-26.

Kline, R. B. (2015). Principles and practice of structural equation modeling: Guilford publications.

Lai, F., Chu, Z., Wang, Q., \& Fan, C. (2013). Managing dependence in logistics outsourcing relationships: evidence from China. International Journal of Production Research, 51(10), 3037-3054.

Lai, K.-h. (2004). Service capability and performance of logistics service providers. Transportation Research Part E: Logistics and Transportation Review, 40(5), 385-399.

Langley Jr, C. J., \& Holcomb, M. C. (1992). Creating logistics customer value. Journal of business Logistics, 13(2), 1.

Lee, H.-Y., Seo, Y.-J., \& Dinwoodie, J. (2016). Supply chain integration and logistics performance: the role of supply chain dynamism. The International Journal of Logistics Management, 27(3), 668-685.

Leuschner, R., Carter, C. R., Goldsby, T. J., \& Rogers, Z. S. (2014). Third-Party Logistics: A Meta-Analytic Review and Investigation of its Impact on Performance. Journal of Supply Chain Management, 50(1), 21-43.

Lin, C.-Y. (2007). Factors affecting innovation in logistics technologies for logistics service providers in China. Journal of Technology Management in China, 2(1), 22-37.

Lu, C.-S., \& Yang, C.-C. (2010). Logistics service capabilities and firm performance of international distribution center operators. The Service Industries Journal, 30(2), 281-298.

Lyles, M. A., \& Salk, J. E. (1996). Knowledge acquisition from foreign parents in international joint ventures: An empirical examination in the Hungarian context. Journal of international business studies, 27(5), 877-903.

Mahoney, J. T. (1995). The management of resources and the resource of management. Journal of Business Research, 33(2), 91-101. 
Mentzer, J. T., \& Konrad, B. P. (1991). An efficiency/effectiveness approach to logistics performance analysis. Journal of business Logistics, 12(1), 33.

Mentzer, J. T., Min, S., \& Michelle Bobbitt, L. (2004). Toward a unified theory of logistics. International journal of physical distribution \& logistics management, 34(8), 606-627.

Morash, E. A., Droge, C. L., \& Vickery, S. K. (1996). Strategic logistics capabilities for competitive advantage and firm success. Journal of business Logistics, 17(1), 1.

Mwangangi, P. W. (2016). Influence of logistics management on performance of manufacturing firms in Kenya. COHred, supply chain managent, JKuat.

Newbert, S. L. (2007). Empirical research on the resource-based view of the firm: an assessment and suggestions for future research. Strategic management journal, 28(2), 121-146.

Newbert, S. L. (2008). Value, rareness, competitive advantage, and performance: a conceptual-level empirical investigation of the resource-based view of the firm. Strategic management journal, 29(7), 745-768.

Nitzl, C., Roldan, J. L., \& Cepeda, G. (2016). Mediation analysis in partial least squares path modeling: Helping researchers discuss more sophisticated models. Industrial Management \& Data Systems, 116(9), 1849-1864.

Olavarrieta, S., \& Ellinger, A. E. (1997). Resource-based theory and strategic logistics research. International journal of physical distribution \& logistics management, 27(9/10), 559-587.

Panayides, P. M., \& So, M. (2005a). The impact of integrated logistics relationships on third-party logistics service quality and performance. Maritime Economics \& Logistics, 7(1), 36-55.

Panayides, P. M., \& So, M. (2005b). Logistics service provider-client relationships. Transportation Research Part E: Logistics and Transportation Review, 41(3), 179-200.

Politis, Y., Giovanis, A., \& Binioris, S. (2014). Logistics service quality and its effects on customer satisfaction in the manufacturing companies' supply chains: Empirical evidence from Greece. Journal of Modelling in Management, 9(2), 215-237.

Rai, A., Pavlou, P. A., Im, G., \& Du, S. (2012). Interfirm IT capability profiles and communications for cocreating relational value: evidence from the logistics industry. MIS quarterly, 36(1), 233- 262.

Ramayah, T., Cheah, J., Chuah, F., Ting, H., \& Memon, M. A. (2018). Partial least squares structural equation modeling (PLS-SEM) using SmartPLS 3.0: An updated and practical guide to statistical analysis: Pearson Malaysia.

Richey, R. G., Daugherty, P. J., \& Roath, A. S. (2007). Firm technological readiness and complementarity: capabilities impacting logistics service competency and performance. Journal of business Logistics, 28(1), 195-228.

Ringle, C. M., Sarstedt, M., \& Straub, D. (2012). A critical look at the use of PLS-SEM in MIS Quarterly. MIS Quarterly (MISQ), 36(1).

Shang, K.-C. (2009). Integration and organisational learning capabilities in third-party logistics providers. The Service Industries Journal, 29(3), 331-343.

Shang, K.-c., \& Marlow, P. B. (2005). Logistics capability and performance in Taiwan's major manufacturing firms. Transportation Research Part E: Logistics and Transportation Review, 41(3), 217-234.

Thatcher, J. B., \& Perrewe, P. L. (2002). An empirical examination of individual traits as antecedents to computer anxiety and computer self-efficacy. MIS quarterly, 381-396.

Tracey, M. (1998). The importance of logistics efficiency to customer service and firm performance. The International Journal of Logistics Management, 9(2), 65-81.

Whipple, J. M., \& Frankel, R. (2000). Strategic alliance success factors. Journal of Supply Chain Management, 36(2), 21-28.

World Bank. (2018). Logistics Performance Index: International LPI. [online]http://lpi.worldbank.org/international(accessed 1st December 2019).

Yang, C.-C., Marlow, P. B., \& Lu, C.-S. (2009). Assessing resources, logistics service capabilities, innovation capabilities and the performance of container shipping services in Taiwan. International Journal of Production Economics, 122(1), 4-20. 
Yang, C.-S., Yang, C.-S., Lirn, T.-C., \& Lirn, T.-C. (2017). Revisiting the resource-based view on logistics performance in the shipping industry. International journal of physical distribution \& logistics management, 47(9), 884-905.

Zhang, Q., Vonderembse, M. A., \& Lim, J.-S. (2005). Logistics flexibility and its impact on customer satisfaction. The International Journal of Logistics Management, 16(1), 71-95.

Zhao, M., Dröge, C., \& Stank, T. P. (2001). The effects of logistics capabilities on firm performance: customer-focused versus information-focused capabilities. Journal of business Logistics, 22(2), 91-107.

\section{Biography}

Liang Hua is associate professor at the Open University of Ningxia of China and Ningxia Polytechnic where he teaches international business, accounting, and supply chain management. He holds a doctorate from the Taylor's University of Malaysia and a master's degree from the Central Queensland University of Australia. He is the author of more than 20 articles in the areas of international business, accounting, entrepreneurship, and logistics.
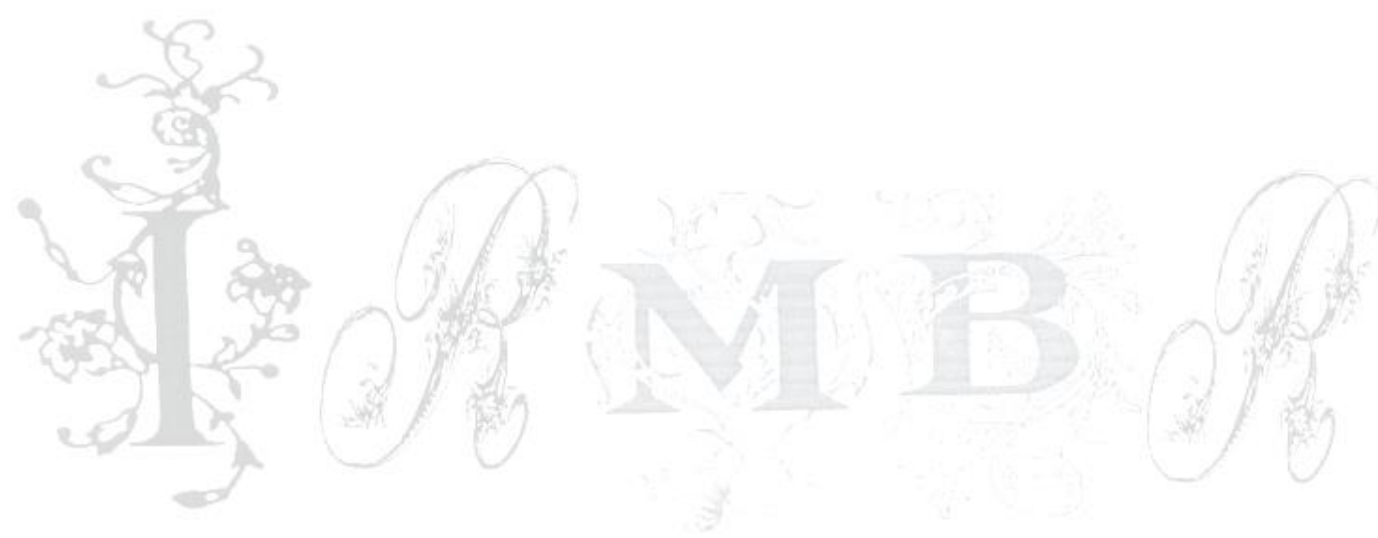